\title{
Matérista
}

Revista Matéria, v. 12, n. 1, pp. 150 - 155, 2007

SSN 1517-7076

http://www.materia.coppe.ufrj.br/sarra/artigos/artigo10860

\section{Preliminary Results of Osteoblast Adhesion on Titanium Anodic Films}

\author{
Doris M. Campos ${ }^{1}$, Emanuel Santos Jr. ${ }^{1}$, Neide K. Kuromoto ${ }^{2}$ and Glória A. Soares ${ }^{1}$ \\ ${ }^{1}$ Metallurgy and Materials Engineering, Federal University of Rio de Janeiro, COPPE/UFRJ, P.O. Box \\ 68505, 21941-970, Rio de Janeiro RJ, Brazil \\ e-mail: doris@metalmat.ufrj.br, emanuel@.ufrj.br, gloria@.ufrj.br \\ ${ }^{2}$ Department of Physics, Federal University of Paraná, P.O. Box 19044, 81531-990, Curitiba PR, Brazil \\ e-mail: kuromoto@fisica.ufpr.br
}

\begin{abstract}
Osteoblast adhesion on metallic titanium coated with anodic films was evaluated. The anodic oxidation treatment was carried out on commercially pure-titanium (cp-Ti) substrate under the following conditions: $1.0 \mathrm{M} \mathrm{H}_{2} \mathrm{SO}_{4} / 150 \mathrm{~V}$ and $1.0 \mathrm{M} \mathrm{Na}_{2} \mathrm{SO}_{4} / 100 \mathrm{~V}$. Osteoblast cells were cultured onto the samples for 4 hours. The morphologies of both $\mathrm{Ti}$ anodic films and cells were observed by scanning electron microscopy (SEM). The oxide films are rough with porous structure. Statistical differences in average surface roughness ( $\mathrm{Ra}$ ) values are found among both anodic films and substrate (abraded cp-Ti), measured by contact profilometry. The oxide films prepared in $\mathrm{H}_{2} \mathrm{SO}_{4}$ had greater contact angle, whereas there is no statistical significance between the values for the Ti anodic films produced in $\mathrm{Na}_{2} \mathrm{SO}_{4}$ and the substrate surface. Despite the some differences in morphology, roughness and contact angle between the treated and nontreated samples, cell morphologies were similar on all surfaces after $4 \mathrm{~h}$ of culture. Further, was not clearly observed a correlation between the surface characteristics with cell behavior.
\end{abstract}

Keywords: Ti oxide films, anodic oxidation, cell adhesion, in vitro tests.

\section{INTRODUCTION}

Titanium (Ti) oxide films produced by means electrochemical treatments have been widely studied in biomaterials field due to their good properties, such as mechanical, corrosion resistance and biocompatibility $[\underline{8}, \underline{10}, \underline{13}]$. The affinity between titanium and oxygen lead to its high corrosion resistance. Further, in vitro tests with simulated body fluid have shown that $\mathrm{Ti}$ anodic films appear to be bioactive [으, $\underline{13}$ ], i.e., they could bond chemically to the bone tissue [] ]. Consequently, these films could be applied to coat titanium dental implants.

The mechanism of cellular adhesion involves several different phenomena. The biocompatibility of materials is closely related to the biological environment and cell adhesion. Some physicochemical features of materials designed for hard tissue replacement, such as surface free energy and topography, play a significant role on osteoblast adhesion [ $\underline{5}$ ]. Cell adhesion and spreading are firstly initiated by means contact cell-biomaterial, and depending on the cell response, proliferation and differentiation are influenced by the surface [1].

The success of implant integration depends on its structure to mimic physiological characteristics, resulting in a cellular recognition and adhesion. This represents a molecular interaction that occurs between the cell surface and extracellular environment. The interaction cell-biomaterial phenomenon is still poorly studied. On the other hand, biocompatibility may be investigated with respect to the development of suitable in vitro tests to evaluate the citoxicity of materials [9].

This work is mostly focused on a preliminary study of osteoblast adhesion on Ti anodic films. The samples were prepared by means anodic oxidation treatment on commercially pure Ti under two different anodizing conditions. Scanning electron microscopy (SEM) is the main technique used to observe the cell morphology and evaluate the osteoblast adhesion.

\section{EXPERIMENTAL DETAILS}

The substrate materials used for anodic oxidation (AO) method were commercially pure Ti (cp-Ti) sheets grade 2 with dimensions of 12x16x0.9 mm³. The samples were abraded with SiC paper (400, 600 and 
1200 grits). The AO treatment was carried out by potentiostatic mode at room temperature (RT) under the following conditions: $1.0 \mathrm{M} \mathrm{H}_{2} \mathrm{SO}_{4} / 150 \mathrm{~V}$ and $1.0 \mathrm{M} \mathrm{Na}_{2} \mathrm{SO}_{4} / 100 \mathrm{~V}$ for 1 minute. A platinum sheet was used as counter-electrode. The oxidized region on cp-Ti sheets corresponds to a $5.2 \mathrm{~mm}$ diameter circle. All samples were ultrasonically cleaned and degreased in pure-ethanol for 15 minutes, washed with distilled water and dried at $40^{\circ} \mathrm{C} / 24 \mathrm{~h}$.

The morphology of the resulting Ti anodic films was observed by scanning electron microscopy (SEM) using a ZEISS DSM 940A microscope working at $15 \mathrm{kV}$. The average surface roughness (Ra) of the resulting specimens was assessed by contact profilometry with a Dektak IIA equipment. Three samples of each anodic film and two samples of cp-Ti substrate were used. Five random areas per sample were chosen for Ra evaluation. $\mathrm{Ra}$ is the average surface roughness, or average deviation, of all points from a plane fit to the test part surface.

Contact angle measurements were performed by the liquid drop method on both Ti anodic films and cp-Ti substrate. The goniometer Dataphysics OCA 15plus was used. A $1.5 \mu \mathrm{L}$ droplet of distilled water was suspended from the tip of a microliter syringe. The syringe tip was advanced toward the Ti anodic films and сp-Ti substrate until the droplet made contact with the sample surface. Then the liquid was dripped onto the surface, and the contact angle $\theta$ between the drop and the substrate was measured. Four samples of each treated surface and substrate were used, and three points were measured for each one. All analyses were performed under RT and same humidity condition. More details on preparation and characterization can be found elsewhere [8].

Osteoblastic cells, named FOST cells obtained from differentiation of endosteal cells and positive for alkaline phosphatase, were isolated from the femurs of mice and kept in DMEM supplemented medium with 10\% FBS and antibiotics. All treated (anodic films) and non-treated (cp-Ti) samples were sterilized at $110^{\circ} \mathrm{C}$ for $24 \mathrm{~h}$, whereas cells were maintained in humidified atmosphere consisting of $5 \% \mathrm{CO}_{2}$ at $37^{\circ} \mathrm{C}$ for 4h. A total number of $1.5 \times 10^{4}$ cells were cultured on each sample. Cells were carefully seeded on the treated surface region to avoid the medium sliding toward the substrate's edge, and preserve the cell concentration previously determined. After 4 hours, the cells were fixed with Karnovisky, post-fixed with $1 \% \mathrm{OsO}_{4}$ and dehydrated through an alcohol series to $100 \%$ and critical point dried. Cell morphology and adhesion were evaluated by SEM using a JEOL JSM-6460LV microscope working at 15kV. Experiments were performed in duplicate. Non-spread and spread osteoblasts were counted by SEM utilizing randomly selected images with magnification of 500x.

Data from the average surface roughness $(\mathrm{Ra})$ and contact angle $(\theta)$ measurements, as well as cell spreading on the surfaces were statistically analyzed by F-Snedecor test (F-test) for a two-tailed test $(P=0.05)$ and Student test (T-test) with $\alpha=0.05$. Statistical significances were considered when the calculated $T$ value $\left(T_{c}\right)$ was greater than $T$ value from T-test two-tailed table $\left(T_{t}\right)$.

\section{RESULTS AND DISCUSSION}

The morphologies of the samples prepared by means anodic oxidation treatment are shown in Fig. 1. According to these images, the morphology of the resulting films varied with anodizing conditions. Titanium anodic films produced with sulphuric acid are porous with regular pore size (Fig. 1a), whereas the films prepared with sodium sulphate are also porous with irregular and in some regions large pores (Fig. 1b). The main formation mechanism of titanium oxide at high anodic potentials occurs due to $\mathrm{O}^{2-}$ ions inward migration (metal-film interface), and $\mathrm{Ti}^{4+}$ ions outward migration (film-electrolyte interface) [4]. The application of high anodic potentials in aqueous medium turns renders the water unstable. According to the Pourbaix diagram [7] oxygen evolution occurs because the applied potentials are much higher than $1.4 \mathrm{~V}$. Another mechanism of oxide film formation is the dielectric rupture. The high electric field generated inside the oxide film, which appears at higher potentials, may be responsible for the pores observed on SEM images. This phenomenon accounts for the morphology of the outer oxide layer. The pores located at the outer film surface are filled with the electrolyte, making these sites preferential to the charge transfer (electric current) and producing $\mathrm{O}_{2}$ bubbles at the film-electrolyte interface [11]. Hence, the pores with spherical shape shown in Fig. 1 are probably related to this effect.

Both treated surfaces shown in Fig. 1 seem to be bioactive in tests performed with simulated body fluid (SBF) $[\underline{8}, \underline{13}]$. After 7 days soaked in $\mathrm{SBF}$ at $37.5^{\circ} \mathrm{C}$, they were able to nucleate some calcium phosphate layer on their surface, and according to KOKUBO et al. (2004) [ㅁ] this in vitro behavior could be a signal of a satisfactory in vivo response. 

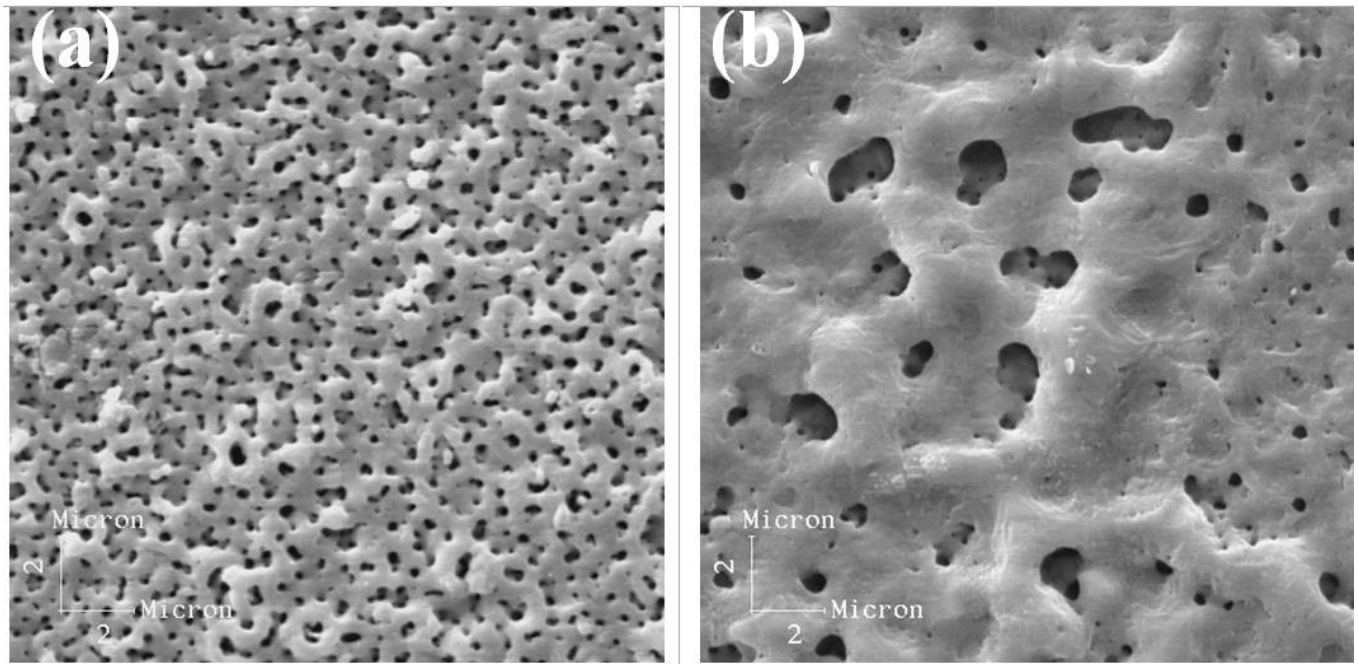

Figure 1: SEM micrographies (5,000 $\mathrm{x}$ ) of the Ti anodic films produced in (a) $1.0 \mathrm{M} \mathrm{H}_{2} \mathrm{SO}_{4} / 150 \mathrm{~V}$, and (b) $0.5 \mathrm{M} \mathrm{Na}_{2} \mathrm{SO}_{4} / 100 \mathrm{~V}$.

Table 1 displays the results of Ra roughness parameter and average contact angle $\theta$ values. The anodic films prepared with $1.0 \mathrm{M} \mathrm{Na}_{2} \mathrm{SO}_{4} / 100 \mathrm{~V}$ are much rougher, whereas the films produced with $\mathrm{H}_{2} \mathrm{SO}_{4}$ are slightly smoother than the abraded cp-Ti substrate. Moreover all Ra values shown in Tab. 1 differed statistically $\left(\mathrm{T}_{\mathrm{c}}>\mathrm{T}_{\mathrm{b}}, \alpha=0.05\right)$. On the other hand, films produced with $\mathrm{H}_{2} \mathrm{SO}_{4}$ had greater average contact angle. Statistical analyses showed that only the average $\theta$ value of this film $\left(1.0 \mathrm{M} \mathrm{H}_{2} \mathrm{SO}_{4} / 150 \mathrm{~V}\right)$ differs from the other ones.

Table 1: Ra roughness parameter and average contact angle $(\theta)$ of cp-Ti substrate and titania films produced at different conditions (mean value \pm standard deviation).

\begin{tabular}{ccccc}
\hline Surface Treatment & Ra $(\boldsymbol{\mu m})$ & $\mathbf{S D}(\boldsymbol{\mu m})$ & $\boldsymbol{\theta}\left({ }^{\circ}\right)$ & SD $\left({ }^{\circ}\right)$ \\
\hline abraded cp-Ti & $0.285^{(\mathrm{a})}$ & 0.046 & $52.89^{(\mathrm{d})}$ & 4.28 \\
\hline $1.0 \mathrm{M} \mathrm{H}_{2} \mathrm{SO}_{4} / 150 \mathrm{~V}$ & $0.230^{(\mathrm{b})}$ & 0.066 & $63.41^{(\mathrm{d})}$ & 14.56 \\
\hline $1.0 \mathrm{M} \mathrm{Na}_{2} \mathrm{SO}_{4} / 100 \mathrm{~V}$ & $0.430^{(\mathrm{c})}$ & 0.285 & $52.32^{(\mathrm{d})}$ & 6.21 \\
\hline
\end{tabular}

(a) $n=10$, (b) $n=15$, (c) $n=13$ and (d) $n=12$.

The main role of some surface features, such as roughness and surface free energy (wettability), in the biological response to materials is still often discussed in biomaterials science [5]. VOGLER (1998) [12] has reported an interesting work, who showed the importance of structure and activity of water at surfaces in biological evaluations. Based on theoretical methods with experimental evidences, is claimed that water adhesion tension $\left(\tau^{\circ}\right)$ is a key measure for biomaterial scientists. The equation $\tau^{0}=\gamma^{0} \cos \theta$ can characterizes surfaces as hydrophilic or hydrophobic, where $\gamma^{\circ}=$ water liquid-vapor interfacial tension $(72.8 \mathrm{dyn} / \mathrm{cm})$ and $\theta$ is the water contact angle [12]. Hydrophobic surfaces exhibit water contact angles greater than $65^{\circ}$ $\left(\tau^{0}<30 \mathrm{dyn} / \mathrm{cm}\right.$, above the Berg Limit), whereas hydrophilic surfaces exhibit water contact angles less than $65^{\circ}\left(\tau^{\circ}>30 \mathrm{dyn} / \mathrm{cm}\right.$, under the Berg Limit). Proteins can adsorb to hydrophobic surfaces, while hydrophilic surfaces support attachment of mammalian cells [12]. According to the classification proposed by VOGLER (1998) [12], all samples herein have hydrophilic surface $\left(\tau^{0}=43.9 \mathrm{dyn} / \mathrm{cm}\right.$ to abraded cp-Ti, $32.6 \mathrm{dyn} / \mathrm{cm}$ to the oxide film prepared in $\mathrm{H}_{2} \mathrm{SO}_{4}$ and $44.5 \mathrm{dyn} / \mathrm{cm}$ to the sample treated in $\mathrm{Na}_{2} \mathrm{SO}_{4}$ ). The oxide films and cpTi substrate thus should be effective on cell attachment.

Figure 2 shows SEM images of the osteoblast cells cultured on the cp-Ti and anodic films for 4 hours. The culture time applied herein is enough to spread some cells onto all surfaces. In Figs. 2a and b is observed that spread cells appear to grow toward the scratches of abrading, i.e., with a preferential direction. Contrarily, cells spread with a non-preferential direction onto both treated surfaces (Figs. 2c, d, e and f). Some proteins of extracellular matrix, which are produced during cell attachment, are mostly noted on the cells in Figs. 2e and f. These attached proteins improve cellular spreading due to a protein interlayer formed 
between substrate material and cells. A part of these proteins interplay with other ones from the cell membrane promoting focal adhesion during the migratory cycle.

The total number of non-spread and spread cells onto cp-Ti and anodic films are presented in Tab. 2. In relation to non-spread cells, it is noted that cp-Ti substrate had much less cells than the anodic films. Statistical analyses confirm the significant difference between the value for cp-Ti and the other ones for the anodic films. However, the total number of spread cells is similar on all surfaces, and there are no statistical differences among them.
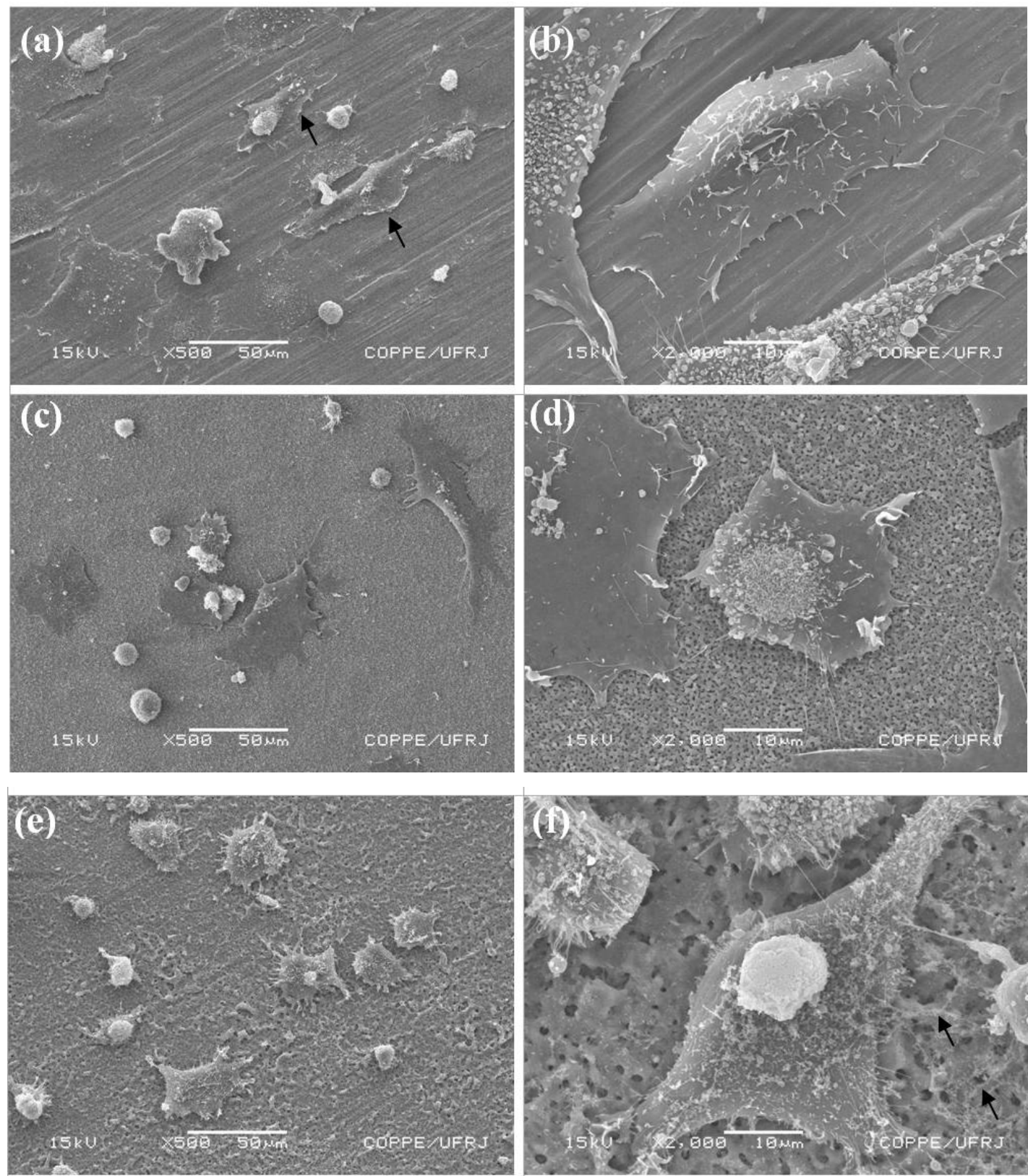

Figure 2: SEM micrographies of osteoblast cells cultured for 4h on (a, b) cp-Ti substrate, and titanium anodic films produced in: (c, d) $1.0 \mathrm{M} \mathrm{H}_{2} \mathrm{SO}_{4} / 150 \mathrm{~V}$, and (e, f) $1.0 \mathrm{M} \mathrm{Na}_{2} \mathrm{SO}_{4} / 100 \mathrm{~V}$. 
Table 2: Total number of non-spread (NS) and spread (S) cells on abraded cp-Ti substrate and titanium films produced at different conditions (mean value $\pm \mathrm{SD}$ ).

\begin{tabular}{ccccc}
\hline Surface treatment & NS (cells) & SD (cells) & S (cells) & SD (cells) \\
\hline abraded cp-Ti & & & \\
\hline $1.0 \mathrm{M} \mathrm{H}_{2} \mathrm{SO}_{4} / 150 \mathrm{~V}^{(\mathrm{b})}$ & 5.333 & 4.287 & 4.667 & 2.257 \\
\hline $1.0 \mathrm{M} \mathrm{Na}_{2} \mathrm{SO}_{4} / 100 \mathrm{~V}^{(\mathrm{c})}$ & 5.538 & 2.504 & 4.538 & 2.025 \\
\hline
\end{tabular}

(a) $n=4$, (b) $n=15$ and (c) $n=13$.

Figure 3 shows SEM micrographs of cells cultured onto titanium anodic films produced in sulphuric acid (Fig. 3a) and sodium sulphate (Fig. 3b). In both cases, pores appear to "anchor" the spread cells onto the anodic film due to the elongation of lamellipodium inward the pores.
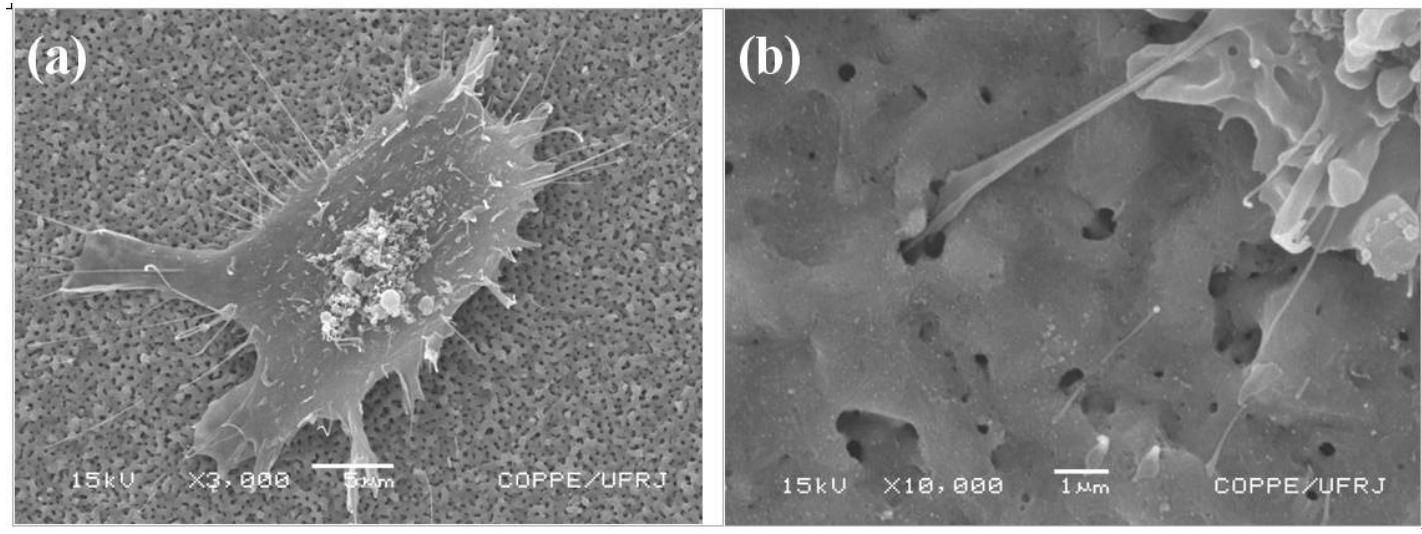

Figure 3: SEM micrographies of osteoblast cells cultured for 4 h on titanium anodic films produced in: (a) $1.0 \mathrm{M} \mathrm{H}_{2} \mathrm{SO}_{4} / 150 \mathrm{~V}(3,000 \mathrm{x})$, and (b) $1.0 \mathrm{M} \mathrm{Na}_{2} \mathrm{SO}_{4} / 100 \mathrm{~V}$.

Regarding the Ra roughness factor, it would be expected that $\mathrm{Ti}$ anodic film produced in $\mathrm{Na}_{2} \mathrm{SO}_{4}$ had much more cells on its surface. But there are no significant difference between the anodic films produced in $\mathrm{Na}_{2} \mathrm{SO}_{4}$ and $\mathrm{H}_{2} \mathrm{SO}_{4}$, as previously described. The treated samples only differed on non-spread cells on their surfaces in relation to the abraded sample (ср-Ti). Even so, the substrate surface is rougher than the oxide film prepared in $\mathrm{H}_{2} \mathrm{SO}_{4}$, and the same number of spread cells is noted on all samples. Therefore, it was not clearly observed a link between Ra factor and number of spread cells on the surfaces. ANSELME \& BIGERELLE (2006) [2] have pointed out that only the Ra parameter would not be sufficient to characterize the surface roughness. Several other parameters should be used to correlate roughness with adhesion, attachment and proliferation of cells [2].

Surface free energy is another factor that seems to influence the cell behavior. This parameter is closely related to the contact angle $\theta$. Materials with low surface free energy (high $\theta$ ) are poorly wettable, spreading, thereby, less cells on their surfaces. But in our experiments are noted similar results from cell behavior on all treated samples. As previously mentioned, the main difference is concerned on non-spread cells onto the substrate and anodic films. It has been investigated that cell behavior seems to be influenced by surface charge [3]], i.e., proteins from FBS go toward the metallic surface and interplay electrostatically. All results indicate that cells spread faster on abraded cp-Ti than the Ti anodic films within 4 hours. The probable modification of surface charge by anodic oxidation on Ti-cp led to these findings. A more extensive study has been carrying out to understand better which parameter, such as roughness, surface free energy and composition has a stronger influence on cells behavior (adhesion, attachment and proliferation) cultured on Ti anodic films produced under different anodizing conditions.

\section{CONCLUSIONS}

Osteoblast cell adhesion on Ti anodic films was studied. All surfaces are rough with Ra parameters statistically different from each other. The anodic film produced in $\mathrm{H}_{2} \mathrm{SO}_{4}$ had a higher contact angle, whereas there is no significant difference between the angles measured on the oxide film produced in $\mathrm{Na}_{2} \mathrm{SO}_{4}$ and the substrate (abraded cp-Ti) surface. Also, both morphology and the number of spread cells are similar 
onto all analyzed surfaces. The findings indicate that cells spread faster on abraded cp-Ti than the Ti anodic films for 4 hours. An extensive study is under development to understand better the roles, separately or sinergically, of the roughness, surface free energy and composition about the cell behavior onto Ti anodic films produced by means anodic oxidation method.

\section{ACKNOWLEDGMENTS}

This work was supported by CAPES, CNPq and FAPERJ Brazilian funding agencies. We are also grateful to Laboratório de Química de Interfaces (PEMM/COPPE/UFRJ) for contact angle measurements.

\section{REFERENCES}

[1] ANSELME, K., “Osteoblast Adhesion on Biomaterials”, Biomaterials, v. 21, n. 7, pp. 667-681, April 2000.

[2] ANSELME, K., BIGERELLE, M., "Modeling Approach in cell/material Interactions Studies”, Biomaterials, v. 27, n. 8, pp. 1187-1199, March 2006.

[3] CAI, K., FRANT, M., BOSSERT, J., HILDEBRAND, G., LIEFEITH, K., JANDT, K.D., "Surface Functionalized Titanium Thin Films: Zeta-potential, Protein Adsorption and Cell Proliferation”, Colloids and Surfaces B: Biointerfaces, v. 50, n. 1, pp. 1-8, June 2006.

[4] HABAZAKI, H., UOZUMI, M., CONO, H., et al., "Crystallization of Anodic Titania on Titanium and its Alloys”, Corrosion Science, v. 45, n. 9, pp. 2063-2073, Sep. 2003.

[5] JONES, F.H., “Teeth and Bones: Applications of Surface Science to Dental Materials and Related Biomaterials”, Surface Science Reports, v. 42, n. 3-5, pp. 75-205, May 2001.

[6] KOKUBO T, KIM H.-M., KAWASHITA, M. et al., "Bioactive Metals: Preparation and Properties", Journal of Materials Science: Materials in Medicine, v. 15, n. 2, pp. 99-107, Feb. 2004.

[7] POURBAIX, M., Atlas of Electrochemical Equilibria in Aqueous Solutions, ed. 2, Houston, NACE International, 1974.

[8] SANTOS JR., E., "Oxidação Anódica de Titânio Comercialmente Puro para Aplicações Biomédicas”, Tese de M.Sc., COPPE/UFRJ, Rio de Janeiro, RJ, Brasil, 2005.

[9] SILVA FILHO, F.C., MENEZES, G.C., "Osteoblasts Attachment and Adhesion: How Bone Cells fit fibronectin-coated Surfaces”, Materials Science Engineering C, v. 24, n. 5, pp. 637-641, Nov. 2004.

[10] TAKEBE, J., ITOH, S., OKADA, J., et al., “Anodic Oxidation and Hydrothermal Treatment of Titanium Results in a Surface that Causes Increased Attachment and Altered Cytoskeletal Morphology of Rat Bone Marrow Stromal Cells in vitro”, Journal of Biomedical Materials Research, v. 51, n. 3, pp. 398-407, Sep. 2000.

[11] TEH, T.H., BERKANI, A., MATO, S., et al., "Initial Stages of Plasma Electrolytic Oxidation of Titanium”, Corrosion Science, v. 45, n. 12, pp. 2757-2768, Dec. 2003.

[12] VOGLER, E.A., "Structure and Reactivity of Water at Biomaterial Surfaces”, Advances in Colloid and Interface Science, v. 74, n. 1-3, pp. 69-117, Feb. 1998.

[13] YANG, B., UCHIDA, M., KIM, H.-M., et al., "Preparation of Bioactive Titanium Metal via Anodic Oxidation Treatment”, Biomaterials, v. 25, n. 6, pp. 1003-1010, March 2004. 